DOIhttps://doi.org/10.36059/978-966-397-158-2/67-82

\title{
CONFLICT FACTORS IN A TRANSIT SOCIETY
}

\section{Zavgorodnya Yu. V.}

\section{INTRODUCTION}

Transit society becomes an intermediate stage in the development of state-building processes, in the formation and establishment of government bodies, in the establishment of a democratic system of interaction of government with citizens. Society is changing and forming a virtually new system of authorities, their hierarchy and mechanism of functioning. At this stage, all changes participants, even passive ones, face misunderstandings and conflicts.

As European countries already have a transit practice, we can speak of the occurrence of recurrence of conflicts in different societies, which requires a thorough generalized analysis and practical universalism for political science and the practical competence of political actors during a conflict in the transit space.

Of course, there are theories in science that do not need to be proved that in state-building processes political conflict constitutes an integral part of the development of the political system, which causes the opposite political parties to improve the level of interaction between the authorities and the society, and thereby stimulate all political subjects to self-improvement. Confrontation, as a social phenomenon, is an integral part of the functioning, and most importantly, of the development of the population and the politicians themselves.

Political transformations continue to evolve and provide the basis for scientific analysis and interpretation in political science. It was in the 1980s that political change began in the direction of the democratic political process.

For the Ukrainian scientific community of political scientists, the issue of transit Ukrainian society is still relevant, as an example of the development of public consciousness and political thought, together with the example of delaying the transition and the emergence of a number of conflict situations, which are the reasons for this. In recent years, we have seen dynamic shifts in the direction of the democratic political system in the management of state-making processes. The transition of society from one political regime 
to another is undoubtedly accompanied by political crises and political conflicts. Today, the political system is beginning to be updated, there is a change of personnel, various directions of action of independent public organizations are being formed, a free form of expression is emerging regarding political subjects and political processes.

Of course, if a comparative analysis of Ukraine with similar transitional processes of other democratic states is to study the political system in the context of the Ukrainian state, it is an indicator of a protracted political process in the direction of socio-political changes.

In the modern geopolitical process, many democratic states are emerging, which are formed as a result of the change from a totalitarian and authoritarian form of government to a democratic one. These are signs of a general civilizational development of the world, which is formed as a result of the maximum modernization of the experience of mankind, and not only in individual countries of the world. Unfortunately, the processes of modernization do not reduce military confrontation, confrontation in the context of interpersonal interaction, conflicts over border demilitarization and many other factors. A number of contradictions are emerging into modern forms of confrontation and influence over one another and become even more dangerous.

When forming a democratic political regime, one should not forget and preserve the heritage of culture as the identification of a nation. An important task for the Ukrainian country, as a state in transition, is to preserve the cultural heritage that has historically emerged in Ukraine. In turn, the task of the entire Ukrainian people is to respect and commemorate traditions and values in different historical periods.

\section{Political conflict in the context of a transit society}

After the collapse of the Soviet Union, a fateful transition begins for statesmen and the entire population, and changes in all socio-political processes take place. All these events are accompanied by difficult conflict processes, protracted crises in the political actions of individual politicians. Such volatile and ambitious processes of politicians and influential citizens of the country delay this process.

Scientists determine the cause of this delay by a sudden process of change, without training the population and managers. Of course, this thesis is quite debatable, since the Ukrainian people have always sought to be independent and substantive, and in fact, throughout their history, people who lived in Ukraine tried to identify themselves, to stand out. That is why, since ancient times, in the conditions of continuous conflict confrontation, a 
group of people has been formed in society, who identify themselves as the people of this land, and therefore require isolation and self-ownership in their own territory.

Considering the vast majority of historical processes regarding the transition to a democratic political regime, there are a number of reasons that delay and plan to slow down this process in the country. Scientists call all these processes of inhibition «factors» or «reasons», «causes», but from this their essence is unchanged. In many countries that have experienced the transition, there are universal, i.e. similar causes of delay, but there are specific causes of delay in a specific territory or individual people. The Ukrainian people have both universal and specific reasons for delaying the transition process.

Conflict, as a manifestation of public opinion and self-expression, is an extreme and rather dangerous form of confrontation in society. There are no conflict-free political processes, there will always be dissatisfied and pessimistic groups of people.

Therefore, political conflicts are increasingly occurring in modern society and, as a rule, do not bring positive results and progress in the development of state-building processes in Ukraine, but rather refer them to countries with unstable legal framework, economically unstable and socially vulnerable state system. ${ }^{1}$

As a result, the grounds that influence the increase of social tensions in Ukrainian society are impoverishment of the vast majority of the population, lack of trust in all public authorities, specific relations between branches of government that publicly influence each other's powers given to them by the state, confrontation between parties, their leaders and others.

In the modern world, conflicts are global in nature and are a natural phenomenon. Therefore, in the event of a conflict in one country, the neighboring country will take all diplomatic measures so as not to affect its internal political system in any way. Given the large-scale value of research and resolution of conflict processes in society for the transit country, it is important to identify prerequisites, objective and subjective causes, motives of conflicts, modeling, search for the best ways to resolve in a timely manner, localization, conversion from violent form to non-violent, prevention which is maturing, not following it. All these circumstances are very important for domestic politics.

Of course, the very nature of conflict in a transit society has to do with understanding the essence of man, his relationship with society and the state.

${ }^{1}$ Білецька Ю. В. Теоретичне визначення політичних конфліктів у сучасній Україні. Актуальні проблеми політики. 2013. Вип. 48. С. 199. 
Any conflict, as it arises in society and exists between people, is always social in nature, that is, a social conflict in the broad sense of the word. In such an interpretation, the conflict is positioned as the collision of two or more different forces in order to realize their social interests in the face of mutual opposition. ${ }^{2}$

The term «conflict» comes from the Latin word «conflictus», which means «collision» in direct translation, and in arbitrary - «opposition», «confrontation». Therefore, scientists define conflict through the concept of antinomy (contradiction) or the concept of struggle (confrontment). Exemplary in this aspect is the explanation of the concept of conflict, proposed by L. Gerasina and M. Panov, who define it as «a manifestation of aggravation of objective and subjective contradictions, which is reflected in the confrontation of its carriers, i.e. the parties» ${ }^{3}$.

Taking into account the peculiarities of political conflict in the society and the peculiarities of the transit society, it can be noted that the longer the conflict process is active and continuous, the longer the transition process is, and the political system is unstable and changeable.

In turn, state power in a transitory conflict society is a weapon of protection and the exercise of power interests. It is worth emphasizing that it is the power interests that arise in the state. Therefore, the most significant difference between political conflict and other social conflicts is that the actors acting in it confront or oppose each other for the main reason - power, control or division. This is the goal pursued by modern political actors in Ukraine. The authorities do not solve the problematic issues, but delay their process (for example, the conflict in the East). In addition, political conflicts arise where interests affect political relations ${ }^{4}$.

Developing a successful country's strategy and tactics is a task for politicians and the community to interact with, and this is not possible without recognizing conflict as an integral part of achieving the set goals. A person's consciousness is capable of critical thinking, and therefore the expression of dissatisfaction is a manifestation of a rational awareness of reality. Such discontent is possible when society does not fully possess objective information about socio-political processes and systematic deception breeds aggression.

\footnotetext{
${ }^{2}$ Бодун Т. І. Особливості феномена конфлікту в державному управлінні. Економіка та держава. 2010. № 5. С. 96.

${ }^{3}$ Бодун Т. І. Особливості феномена конфлікту в державному управлінні. Економіка та держсава. 2010. № 5. С. 96.

${ }_{4}$ Станкевич І. П. Політичний конфлікт та технологія його запобігання. Вісник Київського начіонального університету ім. Т. Шевченка : Філософія. Політологія. 2007. № 87-88. C. 71 .
} 
Thus, a transit society is an indicator of changes in the minds of both society and authorities. When the authorities or society cannot adjust to change, conflicts, dissatisfaction, aggression, and unlawful actions arise that give rise to a lack of confidence between the parties to the conflict. During the reformatting of the political system, changes do not take place in one event (for example, the proclamation of the Act of Declaration of Independence of Ukraine or the approval of the Decree on Non-Nuclear Status). The event of regulatory approval and public announcement is the beginning of future actions, positive or negative.

Since the establishment of an independent Ukrainian state, all major events have taken place under serious contradictions and disputes between politicians and political forces. Adoption of the Basic Law of the state, the Constitution of Ukraine, was accompanied by long discussions and conflicts. The Verkhovna Rada of Ukraine worked continuously for almost 24 hours and as a result, on June 28, 1996, at 9:18 am the Constitution of Ukraine was adopted. Although the Declaration of Independence of Ukraine was adopted on August 24, 1991. For the whole 5 years, the Ukrainian state operated on the basis of the legislation of the Ukrainian SSR. The Basic Law is still incomplete and some of the rules do not apply in practice, although these are rules of direct effect.

In addition, Ukrainian legislation continues to enforce the normative legal acts the Ukrainian SSR. For example, the Housing Code of the Ukrainian SSR, which was adopted in 1983, has been amended several times (the last amendments on January 1, 2019) and is still in effect, and problems in the field of housing and communal services are increasing and not being resolved.

Of course, Ukraine's long membership in the totalitarian Union is one of the reasons for the difficult transition, but it is not an excuse for the Ukrainian statehood and political figures.

For example, consider Lithuania, which independence was recognized in September 1991. The country then joined the UN and the OSCE in 1992. NATO - in 2002, European Community - in 2004. In addition, the updated Constitution was adopted by a nationwide referendum on October 25, 1992. That is, this example follows a clear and sure sequence of actions by political figures on the development of the state, and society takes all measures to support those actions.

Another striking example for the Ukrainian state is the neighboring country of Poland, which was weakened during the Union period, but since the beginning of geopolitical changes in the 1980s and 1990s, Poland has been clearly defining its vector of development, namely developing the 
economy and the administrative sphere and becoming able to join the European Union on May 1, 2004, but does not stop there and on December 21, 2007 becomes a member of the European Union and NATO bloc, joined the Schengen area.

It is worth noting that practically all countries had equal chances and opportunities after the collapse of the Soviet Union to develop their potential, and Ukraine may have had greater chances, resources and opportunities. Due to the economic focus of these resources on the presentday Russian Federation, political forces and individual politicians did not want drastic changes, but rather made the most of the country's full potential for their own purposes. A large-scale privatization of large enterprises has started and it is holding up to date. Privatization of Ukrzaliznytsia, possibly one of the only state-owned enterprises, is on the agenda. The question is quite debatable, there are a number of positive and negative factors.

All statements that the country was not ready for independence, just an excuse for weak politicians, because it fought for independence for a long historical period, a striking example of this is the adoption and proclamation of the first Constitution of Philip Orlyk, who proclaimed the independent country Ukraine by this document. It consists of a preamble and 16 articles. In today's political process, it is seen as a monument of Ukrainian political, philosophical and legal thought. This document did not come into force as it was written in the conditions of exile, but it shows the direct struggle and efforts of politicians and society of that period to the recognition of Ukrainian independence, the impetus to democratization.

The current Ukrainian political reality has a multi-sectoral focus, and all political forces in particular see the development of the Ukrainian state. Integrity, indivisibility and unity are the basic principles that should be applied by both politicians and citizens.

Integrity should be interpreted as the territorial demarcation of a border and its recognition by all international actors. It is very difficult to determine priorities for the direction of development of the state if the population living in these territories does not want or support such development. Ukraine should be united and grouped together by most of all regions in achieving the desired direction.

Indivisibility means the absence of any possibility of isolation of a certain group of people in a separate territory, without division into "yours» and «ours». This will mean a constant struggle, the inability to reach a collective solution, frequent unjustified conflicts. Such actions at the present stage cause a prolonged transitional process. 
Integrity, by this principle, should mean cohesion and tolerance of the subjects of the political process. Their will and democratic spirit in all their actions and endeavors. Therefore, unity means not only the unity of political forces in pursuit of a common goal, but also the support of politicians and vice versa.

It is not possible to build a democratic, legal, social state without a nation that supports its politicians, points them the desired path, and directs their actions in the necessary direction. It is not possible to build a democratic society without the transparent actions of the authorities, which in their activities place the priorities of the people above their own and are governed solely by the rules of law. Strong power, strong people, and vice versa, if every citizen assumes responsibility for the actions of elected politicians, then unscrupulous politicians will become less and the state will be improved and developed.

If we talk about the specific reasons that make it impossible for a real transition to a democratic political regime in Ukraine, they have their cultural and ideological features and need detailed analysis. One of these reasons is not being able, or unwilling, to compromise or consensus when addressing socially important issues.

Compromise, in its essence, in political engagement is one of the essential features of a democratic society. It serves as a decisive principle according to which participants or parties to a political process, when resolving political issues, must agree to concessions, be able to sacrifice particular beliefs or attitudes to reach a crucial issue, and show the public the ability to reach mutual acceptance of intentions and decisions ${ }^{5}$.

The phenomenon of compromise in the political aspiration and democratic formation of the country is a powerful means of preventing socio-political, ethnic, international clashes, mitigating confrontation, overcoming internal crises, avoiding a split in society, but in case of such events, compromise helps the parties to overcome the crisis that their relationship has gone through. Mutual consent in socially significant issues, the ability to make concessions is the highest form of compromise in political issues ${ }^{6}$. At first glance, the simple things of adequate social interaction between the subjects of the political process, but so complicated to implement.

5 Козер Л. Функции социального конфликта. Пер. с англ. Москва: Идея-Пресс, Дом интеллектуальной книги, 2000. С. 12.

${ }^{6}$ Козер Л. Функции социального конфликта. Пер. с англ. Москва: Идея-Пресс, Дом интеллектуальной книги, 2000. С. 12. 
Making compromise decisions is an indicator of maturity and readiness to cooperate to achieve the overriding goal of Ukraine's transition to a democratic political regime to enhance the well-being of Ukrainian society. Political conflicts in Ukraine must be limited in intensity and duration. The parties are obliged to act in the interest of the whole society, otherwise the mechanisms of public administration will be deformed to such an extent that they cannot maintain the balance of public interests ${ }^{7}$.

Along with compromise, consensus plays an important role in the political process. The essence of the consensus mechanism of political parties' interaction is the ability to resolve conflicts in political decisionmaking. That is, the parties to the confrontation should be aware that all misunderstandings have a mechanism of settlement and one of them is a common political decision. Such a decision does not force the parties to make concessions, since this does not require the most problematic issue. The key task of the parties is the ability to negotiate and enforce their own decision.

Consensus inherently encompasses the process of interaction between the parties during which the parties made the decision and the most legally declared decision of the parties. Consensus, in its form, is substantially different from other forms of decision-making, for example by voting, but is effective in its implementation. The parties that actually agree with the decision will demand that the decision be enforced by all policy makers and monitor its implementation.

An important factor hindering the transition to a democratic political regime is certain socio-political processes, namely, external and internal events that influence political processes in the state and contradict the attitudes formed by modern government in society. Ukrainian society is very critical and hostile to changes in the political system offered by the authorities, and so there are certain protests that are accompanied by destructive consequences.

If we analyze the process of transition from a totalitarian regime to a democratic one, namely the turning point of the $80 \mathrm{~s}$ and $90 \mathrm{~s}$, we can conclude that the process of dissatisfaction with the totalitarian system of that period took place in a passive form and not as a planned preparation for radical changes in the social, political process. Therefore, the landmarks of

${ }^{7}$ Валевский А. Failed state Ukraine? Украинская правда. 2009. 19 мая. 
socio-economic, ideological, cultural and other directions of development of Ukrainian independent society have not been determined ${ }^{8}$.

Taking into account all the conflicts and socially important contradictions in the political process, we can say that Ukraine is on the path of modernization. All political changes through reforms and revolutions are aimed at changing the political elites and leaders, changing the vector of development of society, changing the functioning of public authorities, changing the interaction between public authorities and citizens, overcoming large-scale corruption in power, limiting the use of power resources in their own interests.

\section{Factors of conflict in the process of modernization of Ukraine}

The process of modernization in Ukrainian society is very important. If the authorities and the population work together to achieve these goals, it will help Ukraine complete the transition process and embark on the path of a democratic legal society. If the parties miss such an opportunity for modernization, the state may remain in the status of a transit, conflict, fragile country with low economic and cultural development for a long time.

Moreover, since Ukrainian society is post-totalitarian, it is important to pay considerable attention to the responsibility for the consequences of political opposition in domestic socio-political transformations by political actors. In accordance with the requirements of a democratic society, all actors who commit criminal acts in relation to statehood and state-building processes should be punished within the framework of current legislation. In order to comply with international legal instruments ratified by Ukraine and national legislation, the state should punish such political actors within the framework of a sanction.

It is also worth remembering that the lack of transparency in the actions of the judiciary and law enforcement agencies has repeatedly caused conflict between citizens, authorities and politicians, and the number of politicians held accountable does not correspond to the actual number of offenses committed by this category of officials.

However, due to the current political and legal situation in the society, with the advent of a large number of military associations and public organizations, direct pressure is exerted on the judicial and law enforcement agencies. When considering criminal proceedings in which certain actors are of interest, judges cannot resolve the case objectively, which causes a

${ }^{8}$ Кіянка І. Реалізація політичної стабільності в процесі трансформації українського суспільства. Українська національна ідея: реалї та перспективи розвитку. 2009. Вип. 21. C. 91-96. 
violation of the principle of democracy. Interested groups of people gather in courtrooms, who begin to disrupt the lawsuit, use obscene language, create pressure and jitters, and thus violate the lawsuit regulated by procedural law, and encourage the necessary decision.

Such conflicting aspects and problems that arise in the process of democratization are traced back to the fact that the elite, which exercised its powers at the time of the establishment of an independent rule of law, acted in a simplified and unilateral manner towards the implementation of reforms, and therefore showed its unwillingness to carry out the task of effective and rapid transition to the democratic regime, which has delayed the transit period and contributed to a number of political conflicts.

The scientific studies and historical events of the independent Ukrainian state trace a number of reasons that made it impossible for a rapid transition of society to the desired political regime.

The basic reasons for changes in the political system of the state are subjective composition. In the Ukrainian society, changes were made mainly by the same staff, which necessitated these changes. All political decisions regarding the transformation of society were made taking into account the interests of individuals, not the entire Ukrainian society.

Modern reforms and targeted programs that are practically hierarchical, i.e. top-down, are often ineffective and do not work in practice. All the norms and tenets of the change process are general in nature and do not have a clear procedure for implementation. The lower structural forms of society do not support the reform of power, since they do not affect the creation of these reforms, which create possible directions for change. Lack of forms of cooperation between authorities at all levels causes conflicts on various socially significant issues.

Another important factor that causes contemporary political conflicts in Ukraine is the illusion of a conflict-free society. For a long period of time, people are not able to apologize publicly, negotiate and discuss problematic issues. The solution of any political conflict, which is inherently a public phenomenon, is made in the national society in «closed offices». In this regard, there is a growing distrust of the authorities, distrust of politicians, distrust of the entire state apparatus at all levels.

Contemporary scholars emphasize the isolation of ideological conflict, which shows the peculiarities of traditional research, and at the same time characterizes the process of state transformation. Ukraine is an exemplary example of such conflict counteraction, since confrontation of ideologies is an important signal for public figures about the possible serious consequences of such conflict, the confrontation in the political process and the irresponsibility of the consequences of the parties' actions. 
Also, in today's Ukrainian society, which is in a virtually indeterminate status regarding the form of government, there is usually always a confrontation between two parties related to the degree of public confidence in the government. Such value-cultural processes are the legitimation and delimitation of the new political regime in society, which include the recognition of political leaders, the renewed structure of state and non-state institutions in society.

The phenomenon of instability of Ukrainian society in the transit period shows us that the process of legitimation and delegitimization is quite relevant, and that society shows its value in state-building events and shaping the direction of the country's development. During such events, the idea is formed that society is not a gray mass, these are communicative and active citizens, intellectually aware.

Socio-political confrontations, dubbed the Revolution of Dignity in the media, are a direct example of the importance of legitimizing power, the people can forgive the authorities for lack of legality, as happened with the authorities after the Revolution of Dignity, but Ukrainian society will not restrain itself if power does not restrain.

Power delegitimation in the Ukrainian political system is a dangerous means of changing power, as it can have uncontrolled actions and therefore lead to unexpected consequences. The government exhausts all the credit of trust and cannot control the socio-political processes, which may eventually end in the collapse of statehood. In a democratic society, legality and legitimacy are the pledge of the power of the people, and therefore these concepts and political actions are not indivisible and interconnected.

In a transition period characterized by a large number of socio-political changes, society forgives the authorities for lack of stability and sharp socioeconomic fluctuations, but these are only temporary phenomena, since the internal instability of the transit society over time contributes to exacerbation of various problems encountered by the population.

One of the key problems of the transition period is the corruption of the authorities at all levels, and the conflict of political decisions is a confirmation of this. Every political force tries to influence some or other political decisions made in the state, in a favorable direction for them. One of the issues that politicians are in no hurry to address is the legitimacy of amber mining. Many media outlets have been covering the confrontation within the framework of illegal amber mining, the issue has become nationwide and still remains unresolved.

Taking into account all the important factors that influence the emergence of conflicts in the transition period of Ukrainian society, it is necessary to emphasize the attention and life circumstances of citizens, historical peculiarities of the society development. The life circumstances of development and functioning are to change the views of individual members 
of society, taking into account objective and subjective reasons, regarding the historical past, the desired future and the improvement of the present. In this context, a new model of national identity is emerging, perhaps even with a dramatic change in cultural and historical values.

V. Gorbatenko notes the existence of the phenomenon of the «Ukrainian model» of post-totalitarian development, which, for all its economic inefficiency, is capable of maintaining peace in the country and avoiding open internal aggression and bloodshed. The formation of such a model takes effect in the exercise of the powers of the first president, L. Kravchuk. Its main purpose is that the authorities wished to maintain social equilibrium while not essentially changing the socio-political system, maintaining the current system and institutions of the authorities, because there was a fear that there would be a disorder in society and the collapse of the administrative system ${ }^{9}$.

The result of the implementation of such a model is, firstly, the absence in the first years of independence of large-scale conflicts, with negative violent consequences, secondly, the lack of development and economic recovery. The country was dominated by fear of the development of conflicts, which persisted from a totalitarian society, because in its normal manifestation conflict is necessary for the democratic development of society. The existence of contradictions in society is characterized by a certain manifestation of the struggle against the outdated totalitarian leadership structures and the formation of civil society.

A society that intends to shape a democratic political regime is bound to fulfill the basic principles that will stimulate change in consciousness, namely: equality of citizens in all characteristics and indicators without restriction and oppression by color, origin, language and religious affiliation. All of these principles in modern Ukrainian society often lead to the development of socio-political and ethnic conflicts that can lead to the most dangerous consequences. From time to time, such confrontations may integrate several factors of conflict and develop nationwide or globally.

Therefore, taking into account all the above, it can be noted that all the factual circumstances that give rise to conflict are reduced to the main generalization, that the main goal of the transit society of Ukraine is to achieve political and economic stability. At the present stage of the existence and functioning of Ukrainian society, it is possible to identify the main changes in the creation of a democratic political society in the country, namely:

9 Долженков О. Посткомуністичні трансформації в країнах Центрально-Східної Європи та СНД: порівняльний аналіз. Нова політика. 2000. № 5. С. 12-13. 
- firstly, there was a change of personnel in the system of public authorities, which contributed to the emergence of new ideas in the interaction of the authorized person and the citizen;

- secondly, values in the Western industrial world began to change in the Ukrainian society during the transformation period, which means that the state in its activity is also beginning to transform and change the vector of development;

- thirdly, in economic terms, there is a need to fulfill certain conditions to achieve the desired result, which would correspond to the level of European countries, because there is a market for domestic goods, and therefore there is a lively competition. Economic factors today often cause credit and currency problems, as a result of rising unemployment and emigration ${ }^{10}$.

Of course, the issue of transit for Ukrainian society will be urgent for an indefinite period of time, since at the present stage there is no effective mechanism for the transition to a democratic political regime, and the consciousness and mentality of citizens, as key levers of democracy, are not geared for rapid changes in all sectors, such as the state and public life in general. Citizens' consciousness and political views are scattered in different directions. Such multidimensionality limits the effective path of transition.

Therefore, the democratic political regime is one of the most important goals for the political authorities and the Ukrainian people, because it is the desire for better political change, the main thing that such desire is for both the political elite and the overwhelming majority of citizens to jointly move towards its achievement.

Modern realities show us that political power also includes interstate ties of individual political forces that are capable of influencing peoples and nations, thereby increasing the geopolitical influence of individual politicians and political forces. The concept of political power goes beyond the interpretation of governing bodies within one country.

In addition, it is worth paying attention to the hierarchy of power and interconnections in the modern information world, since the power hierarchy is changing somewhat.

According to Bulbenyuk S.S. one of the illustrative arguments regarding the need to rethink public authorities' public awareness in the information age is the emergence in the last decades of alternative centers of making important political and managerial decisions - centers of a network nature. The author argues that, like traditional state institutions, political parties, political leaders and elites, such networking centers do not require institutionalization and formalization. The essence of alternative networking

10 Завгородня Ю. В. Особливості розвитку транзитного суспільства в умовах політичного конфлікту. Актуальні проблеми політики. 2018. Вип. 61. С. 235. 
centers is ambiguous, since, on the one hand, such centers can be formed on social networks, which means that they should be as open and public as possible in their activities, and on the other hand, often outside such centers are elite representatives, which do not contain any elements of publicity. Therefore, the general public (those who are commonly called «people», «ordinary citizens», «voters», «civil society») have no idea about the true nature of such representatives of the political elite ${ }^{11}$.

Thus, taking into account S. Bulbenyuk's statement, we can say that the modern political power has changed peculiarities regarding public influence and interaction with the society, and the structure of the government does not have a clear approved pattern of interconnections and rules of behavior regarding the entry into the power structure. The newest aspects of political power are characterized by the presence of informal centers of influence, the lack of power, or even in some places, the unsettled power relations ${ }^{12}$.

Since power has such characteristics in current political processes, there is a certain power struggle, or so-called sphere of influence, on groups of people or regions. The power itself in the process of interaction, due to frequent conflict processes, becomes a state of political crisis, which leads to devastating processes for the entire structure of government.

As E. Toffler wrote in his famous work, The Shift of Power: Knowledge, Wealth, and Violence at the Threshold of the Twenty-First Century, the system of power pervades modern society to the core, no one is free from it $^{13}$. However, if we cannot be free from power, then we must form it in such a way that this power is effective in the interaction of different political institutions and in relation to citizens.

In transitional societies, it is very important that the effectiveness of political power is determined by the results of the implementation of developed plans, programs, its ability to manage effectively all spheres of public life, to achieve political goals by optimal means. There is no universal notion of «power efficiency» in scientific circulation that can be used to define objectively power by quality. Although in its general form, the effectiveness of power is the use of all possible levers of influence to satisfy the interests of citizens. Therefore, if the government uses leverage to satisfy its own interests, then it is the corruption efficiency of the government that needs radical changes.

11 Бульбенюк С. С. Особливості владно-управлінського дискурсу в інформаційну епоху. Науковий часопис НПУ імені М.П. Драгоманова. 2014. Вип. 14. С. 66.

12 Бульбенюк С. С. Особливості владно-управлінського дискурсу в інформаційну епоху. Науковий часопис НПУ імені М.П. Драгоманова. 2014. Вип. 14. С. 66.

13 Жаровська I. М.Державна влада: правові категорії: Монографія. Львів: Вид-во Львівської комерційної академії, 2012. С. 26. 


\section{CONCLUSIONS}

Considering all the above, we can conclude that the peculiarity of the transit society, besides the struggle for the distribution of powers, for determining the spheres of influence, there are problems regarding the efficiency of the allocation of economic resources in the state. That is why the populist anti-corruption thesis has to move from slogans to actions in order to speed up the transition period.

The current political situation in Ukrainian society demonstrates the most dangerous consequences for the authorities and society as a whole. As conflicts ripen in both society and power, tension and psychological strain on the minds of citizens increases, emotions and aggression often become the norm of communication.

In the current political process, the destruction of political power, which is the result of protracted political conflicts that go into prolonged crisis states, is of great importance, making it impossible for a democratic political regime to emerge.

Thus, transit society is emerging in the face of a series of political conflicts and political crises that have a significant impact on the process of modernizing the political system.

Authorities are pushing for positive change by improving their knowledge, skills and abilities. Conflict over key forms of development limits the ability to improve quickly the political system, and parties to conflict are unwilling to compromise on a swift settlement.

Conflicts are the way to find a way to democratize the political system and society. Changing the political regime is not only a change of the elite, it is also an awareness of the responsibility of every citizen who is a power, not an instrument of power in the old political elite.

\section{SUMMARY}

In scientific research on the signs of conflict in a transit society, scientific analysis of political confrontation in the historical context of political events and political decisions that influence the further development of society is of great value. The main tasks are to carry out a comparative analysis of the factors of conflict in post-totalitarian countries, to create a list of causes of conflict with the definition of their influence on a transitional society, and to analyze the Ukrainian society as a stable transit country. The source of the conflict is not only the cause of the delay in the transition process in society, but also the factor of destructive processes, which have a negative component in the development process. The analysis of current problems will help to determine what priorities should be taken by the political elite during the process of transformation in the political consciousness of one's own and society as a whole. 


\section{REFERENCES}

1. Білецька Ю. В. Теоретичне визначення політичних конфліктів у сучасній Україні. Актуальні проблеми політики. 2013. Вип. 48. С. 199208.

2. Бодун Т. I. Особливості феномена конфлікту в державному управлінні. Економіка та держава. 2010. № 5. С. 96-100.

3. Бульбенюк С. С. Особливості владно-управлінського дискурсу в інформаційну епоху. Науковий часопис НПУ імені М.П. Драгоманова. 2014. Вип. 14. С. 66-70.

4. Валевский A. Failed state Ukraine? Украинская правда. 2009. 19 мая.

5. Долженков О. Посткомуністичні трансформації в країнах Центрально-Східної Європи та СНД: порівняльний аналіз. Нова політика. 2000. № 5. С. 12-16.

6. Жаровська I. М. Державна влада: правові категорії: Монографія. Львів: Вид-во Львівської комерційної академії, 2012. 195 с.

7. Завгородня Ю. В. Особливості розвитку транзитного суспільства в умовах політичного конфлікту. Актуальні проблеми політики. 2018. Вип. 61. С. 226-235.

8. Кіянка I. Реалізація політичної стабільності в процесі трансформації українського суспільства. Українська національна ідея: реалії та перспективи розвитку. 2009. Вип. 21. С. 91-96.

9. Козер Л. Функции социального конфликта. Пер. с англ. Москва: Идея-Пресс, Дом интеллектуальной книги, 2000. 208 с.

10. Станкевич І. П. Політичний конфлікт та технологія його запобігання. Вісник Київського національного університету ім. Т. Шевченка : Філософія. Політологія. 2007. № 87-88. С. 71-73.

\section{Information about the author: Zavgorodnya Yu. V., $\mathrm{PhD}$ in Political Sciences,} Associate Professor at the Department of Political Theories of the National University «Odessa Law Academy» 2, Academichna str., Odesa, 65009, Ukriane 